Antioxidant capacity of the wild fruit pipisco (Jaltomata procumbens), and its application in the preparation of a sauce

\title{
Capacidad antioxidante del fruto silvestre pipisco (Jaltomata procumbens), y su aplicación en la preparación de una salsa
}

Martha Navid Mendoza-Rodríguez ${ }^{1}$, Leobardo González-Barraza ${ }^{1}$, Lisbet Argüelles-Martínez², Iván Hernández-Ramírez ${ }^{2}$, Margarita Cervantes-Rodríguez², Omar Rodríguez-Salazar², Oscar Antonio Aguilar-Paredes ${ }^{2}$, Daniel Méndez-Iturbide*2

${ }^{1}$ Maestría en Biotecnología y Manejo de Recursos Naturales, Universidad Autónoma de Tlaxcala, México.

${ }^{2}$ Laboratorio de Química de la Nutrición de la Licenciatura en Nutrición de la Universidad Autónoma de Tlaxcala, México.

*e-mail: danychem@yahoo.com.mx

https://doi.org/10.29267/mxjb.2016.1.2.83

\begin{abstract}
In this work, the antioxidant capacity of the wild fruit (Jaltomata procumbens) commonly known as "pipisco" was determined. The evaluated samples were: a) Fresh pipisco, b) Pipisco subjected to heat treatment, c) A preparation of a sauce with fresh pipisco and d) Pipisco's extracts. The antioxidant capacity was determined by spectrophotometric methods ABTS (2,2'azino-bis(3ethyl benzothiazoline-6-sulfonic acid) diammonium salt), DPPH (2,2-diphenyl-1-picryl-hydrazyl), TBARS (thiobarbituric acid reactive substances), total carotenoids and polyphenols. In the test of ABTS and DPPH there was evaluated the aptitudes of the sample to trapping the radicals previously mentioned, the reductions of the free radicals was $69.21 \% \pm 0.92$ and $95.08 \% \pm 3.38$ respectively. In the TBARS there decided a percentage of inhibition of lipoperoxidation of $40.24 \%$. The results in the total carotenoids content were $6.88 \pm 0.05 \mu \mathrm{g} / \mathrm{g}$ of sample. The concentration of the total polyphenols in the fruit was $0.2621 \pm 1.074 \mathrm{mg}$ equivalents of the gallic acid/g per fruit.
\end{abstract}

Keywords: antioxidant activity, Jaltomata procumbens, sauce, TBARS. 


\section{RESUMEN}

En este trabajo se determinó la actividad antioxidante del fruto silvestre (Jaltomata procumbens), conocido popularmente como "pipisco". Las muestras evaluadas fueron: a) el pipisco en su estado natural, b) Sometido a un proceso de cocción, c) Una preparación en salsa con pipisco, y d) En extracto. La actividad antioxidante fue determinada mediante los métodos espectrofotométricos ABTS (ácido 2,2-azinobis-3-etilbenzotiazolin-6-sulfonico, sal diamónica), DPPH (2,2-difenil-1picrilhidrazil), TBARS (sustancias reactivas al ácido tiobarbiturico), carotenos totales y polifenoles. En la prueba de ABTS y DPPH se evaluó la capacidad de las muestras para atrapar los radicales antes mencionados, la reducción de los radicales libres fue de $69.21 \% \pm 0.92$, y $95.08 \%$ \pm 3.38 , respectivamente. En la prueba de TBARS se determinó un porcentaje de inhibición de lipoperoxidación de $40.24 \%$. Los resultados en el contenido total de carotenoides fue de $6.88 \pm$ $0.05 \mu \mathrm{g} / \mathrm{g}$ de muestra. La concentración de polifenoles totales presentes en el fruto fue de $0.2621 \pm$ $1.074 \mathrm{mg}$ equivalentes al ácido gálico/g de fruta.

Palabras clave: actividad antioxidante, Jaltomata procumbens, salsa, TBARS.

\section{INTRODUCTION}

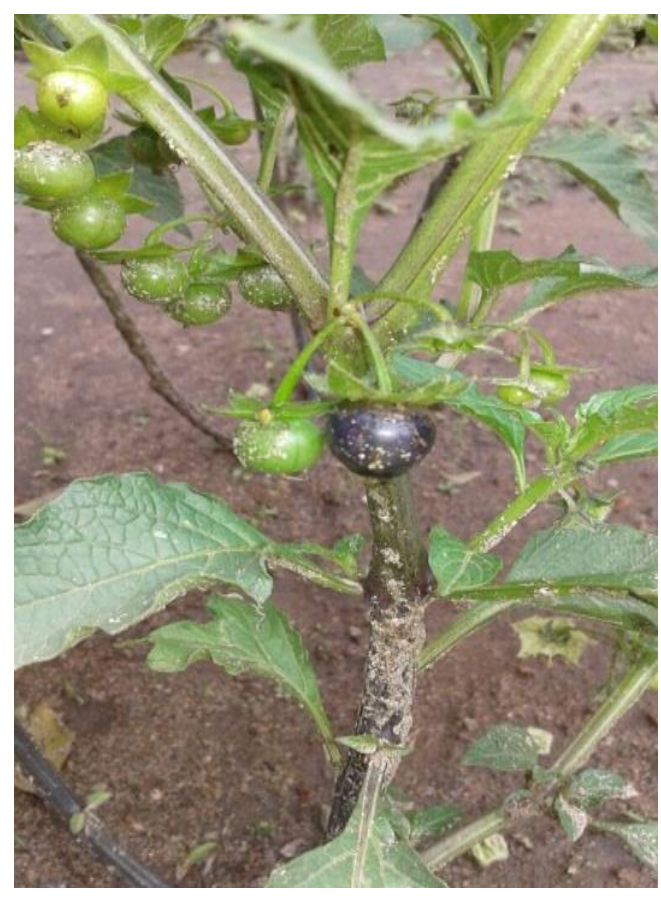

Figure 1. Jaltomata procumbens fruits 
Solanaceae are one of the most economically important plant families on a global scale and Mexico is recognized as a country with a great biodiversity for this type of crops (Davis \& Bye 1982; Benítez, 2010). Pipisco (Jaltomata procumbens Cav.J.L.Gentry) is a native plant of the south of Mexico, however, it grows from the south-west of the United States up to the Andes. It a plant that grow up erect with leafy green stem, which can reach $1.5 \mathrm{~m}$ height. It has simple sheets with smooth rim; flowers of whitish green or pale yellow; the fruit is a round juicy berry of bittersweet flavor. It has small seeds and possesses a characteristic purple flesh, which is consumed basically in fresh, however it is also used for the preparation of some traditional dishes. The season's fruit goes on July-October; they are often between the cornfields, although in spite of its tropical origins they tolerate some frosts (Saldivar et al., 2010). The pipisco in its maturity presents purple coloration possibly this coloration is attributed by anthocyanins, this type of metabolites has antioxidant activity that works as a free radical scavenger of oxygen (Garzon, 2008).

The free radicals are produced normally during the aerobic metabolism in the human being, they are present in diverse physiological processes, like a defense mechanism against infectious agents (Delgado et al., 2010; Hernández \& McCord, 2007). They are integrated principally of reactive oxygen species (ROS) and reactive nitrogen species (RNS) (Halliwell, 2010). When high free radicals concentrations exist the oxidizing stress is originated, which is a condition that is evident in the organism, when the production of highly reactive substances overcomes the antioxidant capacity mechanism (Luna \& Delgado, 2014).

The antioxidants are compounds capable of inhibiting or slowing down the oxidation by the reception of free radicals (Krinsky, 1989). They have been classified in accordance of their chemical structure and biological function, dividing them in endogenous and exogenous. The endogenous antioxidants are a group of enzymes specialized in neutralizing the ROS by different mechanism, such is the case of the superoxide dismutase (SOD), the catalase (CAT) and the glutation peroxidase (GPX), for example (Martínez et al., 2002). The exogenous antioxidants are those compounds that are obtained from the diet, as selenium, zinc, riboflavin, retinol (vitamin A), ascorbic acid (vitamin E), carotenoids and flavonoids (Magalhães et al., 2008). Due the relevance of the biological antioxidant function, in the last years methods have developed to evaluate the antioxidant capacity, the most used methods are ABTS, DPPH based on the 
generation of free radicals form certain organic molecules and TBARS oxidation of LDLs (Kuskoski et al., 2005). The aim of this research was to determine the content of bioactive compounds and antioxidant capacity of a) fresh pipisco, b) boiled, c) the final product of mixture prepared with onion, garlic, chili and pipisco (sauce) and d) extract pipisco; as well as evaluate the antioxidant capacity by influencing thermal processes.

\section{MATERIALS AND METHODS}

Mature fruits were collected in the community of Carmen Aztama, belonging to the municipality of San Luis Teolocholco, Tlaxcala México 19¹3'54.5'N 98 $13^{\prime} 10.5^{\prime \prime} \mathrm{W}$ in September 2015. The selection criteria were: similar size and color, free of bruises and in complete ripeness.

\subsection{Preparation of the samples for the experiments a-d}

For the characterization of the antioxidant capacity of a sauce (sample c) prepared with pipisco, two alternative treatments were analyzed (samples b and d), plus a fresh fruit control (sample a) as follows: a) $100 \mathrm{~g}$ of fresh pipisco; b) $120 \mathrm{~g}$ of stew pipisco subjected to a heat treatment in $300 \mathrm{~mL}$ of water for 7 minutes at $90{ }^{\circ} \mathrm{C}$; c) $150 \mathrm{~g}$ of fresh pipisco for the sauce, $60 \mathrm{~g}$ of onion (Allium cepa), $25 \mathrm{~g}$ of serrano chili (Capsicum annuum) and $5 \mathrm{~g}$ of garlic (Allium sativum). All this ingredients were roasted and ground d) Obtaining extracts: it was used $350 \mathrm{~g}$ of fresh pipisco lyophilized at $-50{ }^{0} \mathrm{C}, 0.014$ mbar of pressure for 72 hours, obtaining $36 \mathrm{~g}$ of lyophilized pipisco. For the extracts preparation sequential extractions are developed using $30 \mathrm{~g}$ of the biological sample, starting with $300 \mathrm{~mL}$ of $n$-hexane, dichloromethane, ethyl acetate, acetone, ethanol and methanol, bottled in an amber color jar for 72 hours to $25{ }^{\circ} \mathrm{C}$ for every dissolver and using the same biological sample. Subsequently it evaporates to dryness with a rotary evaporator in a temperature between 35 to $50{ }^{\circ} \mathrm{C}$.

\subsection{Neutralization of the ABTS radical cation}

The procedure is described by (Kuskoski et al., 2005), which consists in producing the radical ABTS $7 \mathrm{Mm}$ by the solution of ABTS $7 \mathrm{mM}$ with potassium persulfate $2.45 \mathrm{mM}$ (final concentration). It is mixed and incubated in the dark from $12-16$ hours at $25^{\circ} \mathrm{C}$. Once formed the radical is diluted by ethanol until obtaining an absorbance value from 0.70 to $436 \mathrm{~nm}$ in a spectrophotometer Genesys 10 UV, Thermo Electron Co. U.S.A.). 
$25 \mathrm{~g}$ of the different samples were used ( $\mathrm{a}, \mathrm{b}$ and $\mathrm{c}$ ). There was added a mixture of $20 \mathrm{~mL} \mathrm{of}$ ethanol-acetone 1:1 under agitation for 1 hour to $25^{\circ} \mathrm{C}$. It was filtered with cotton and it was centrifuged at $12000 \mathrm{rpm}$ for 5 minutes, finally taken $10 \mu \mathrm{L}$ and are added $990 \mu \mathrm{L}$ of the radical ABTS $^{*}$ previously obtained. For the sample d, it was used $10 \mu \mathrm{L}$ of the extracts at final concentration of 10,100 and $1000 \mathrm{mg} / \mathrm{L}, 990 \mu \mathrm{L}$ of the solution of the $\mathrm{ABTS}^{\bullet+}$ is added and it is monitored every minute for 6 minutes.

\subsection{Free radicals neutralization by DPPH}

It is used a free radical DPPH solution, at a concentration of $133.3 \mu \mathrm{M}$ dissolved in ethanol. It is added $200 \mu \mathrm{L}$ of ethanol in Elisa plaques that are used as diluent, in other pot were added $150 \mu \mathrm{L}$ of DPPH solution and $50 \mu \mathrm{L}$ of the prepared sample to analyze a, b and c. For the sample d, it is used $50 \mu \mathrm{L}$ of each extract so the final concentrations are of 10,100 y $1000 \mathrm{mg} / \mathrm{L} .150 \mu \mathrm{L}$ of solution of DPPH are added, is incubated for 30 minutes at $37{ }^{\circ} \mathrm{C}$ with orbital agitation. The lectures are made at $\lambda=517 \mathrm{~nm}$ in a microplaque reader (Bio-Tek EL800, U.S.A.), the percentage of activity is calculated in base on the initial concentration of the free radical DPPH, using the DPPH radical reduction percentage formula $=[(\mathrm{C}-\mathrm{E}) / \mathrm{C}] \times 100$, where:

$\mathrm{C}=$ control absorbance

$\mathrm{E}=$ Absorbance of the evaluated sample.

\subsection{Lipid peroxidation induced by iron rat brain homogenate (TBARS)}

Is worked with rat male from Wistar strain, using $2 \mathrm{~g}$ of brain. The brain tissue of rat is quickly dissected and waste of blood is removed with a saline solution $0.15 \mathrm{M}$, it gets the homogenized with a glass Potter-Elvehjem homogeniser using $10 \mathrm{~mL}$ of phosphate buffer saline (PBS) $0.1 \mathrm{~m}$ $\left(0.2 \mathrm{~g}\right.$ of KCl, $0.2 \mathrm{~g}$ of $\mathrm{KH}_{2} \mathrm{PO}_{4}, 8 \mathrm{~g}$ of $\mathrm{NaCl}$, and $2.16 \mathrm{~g}$ of $\left.\mathrm{NaHPO}_{4} .7 \mathrm{H}_{2} \mathrm{O} / \mathrm{L}\right)$ per gram of brain, at $\mathrm{pH} 7.4$ and temperature of $5{ }^{\circ} \mathrm{C}$ per gram of brain. The homogenate is centrifuged at $3000 \mathrm{rpm}$ for

10 minutes, take the supernatant and determines the content of protein by the method described by (Lowry et al., 1951). Adjusting to $2.66 \mathrm{mg}$ of protein/mL with phosphate buffer, using bovine serum albumin as standard. The supernatant $(375 \mu \mathrm{L}, 1 \mathrm{mg}$ of protein) is placed in $1.5 \mathrm{~mL}$ Eppendorf tubes, add $50 \mu \mathrm{L}$ of EDTA, you add $25 \mu \mathrm{L}$ PBS and $25 \mu \mathrm{L}$ of the sample a, b and c prepared with the method described above, for the sample $\mathrm{d}$ add $50 \mu \mathrm{L}$ of each extract to generate in concentrations of work 10,100 and $1000 \mathrm{mg} / \mathrm{L}$, incubated at $37{ }^{\circ} \mathrm{C}$ for 30 minutes. The 
peroxidation is initiated with the addition of $50 \mu \mathrm{L}$ of $\mathrm{FeSO}_{4}$ freshly prepared (final concentration $10 \mu \mathrm{M}$ ) (Rainov, 2000) is continued incubation for one more hour. After the tubes are immersed in an ice bath and add $0.5 \mathrm{~mL}$ of reagent TBA (1\% of thiobarbituric acid in $0.05 \mathrm{~N} \mathrm{NaOH}$ and $30 \%$ trichloroacetic acid 1:1) the mixture is heated to $94{ }^{\circ} \mathrm{C}$ for 30 minutes, then centrifuge at 12000 rpm for 10 minutes. The assessment of the scope of the lipid peroxidation was determined for each sample according to the production of MDA (malondihaldehyde) of supernatant by the development of the TBARS assay described by (Kibanova et al., 2009). Take $200 \mu \mathrm{L}$ of supernatant and the optical density is determined at $\lambda=540 \mathrm{~nm}$ in a microplate reader. The targets for each sample are prepared and valued in the same way to exclude any external contribution. The result of TBARS were expressed as equivalent of MDA using standard 1,1,3,3tetramethoxypropane (Esterbauer \& Cheeseman 1990). The percentage of inhibition is defined as the decrease in the formation of TBARS due to the chelation of the extracts and is calculated as follows:

$\%$ inhibition $=[(\mathrm{C}-\mathrm{E}) / \mathrm{C}] \times 100$ where:

$\mathrm{C}=$ absorbance of control

$\mathrm{E}=$ absorbance of the sample to assess.

\subsection{Quantification of total carotenoids}

Used $2 \mathrm{~g}$ of the sample $\mathrm{a}, \mathrm{b}$ and $\mathrm{c}$, add $10 \mathrm{~mL}$ of hexane/acetone/ethanol (50:25:25, v/v), and is under orbital shaker for 1 hour at $25^{\circ} \mathrm{C}$, centrifuge for 5 minutes at $6500 \mathrm{rpm}$. Finally left to rest at $5{ }^{\circ} \mathrm{C}$ for 1 hour. The upper phase is separated out and dilute to mark to $25 \mathrm{~mL}$ with $n$-hexane. Take an aliquot of $1 \mathrm{~mL}$ and measured the absorbance six times in a Genesys $10 \mathrm{UV}$ to $450 \mathrm{~nm}$, used the extinction coefficient of $\beta$-carotene $\varepsilon=2505$ and is reported as $\mu \mathrm{g} / \mathrm{g}$ of sample according to the formula:

$\mathrm{x}(\mu \mathrm{g})=*$ and $(\mathrm{mL}) 106 /$ to $1 \mathrm{~cm} 1 \% 100$

$\mathrm{x}(\mu \mathrm{g})=\mathrm{x}(\mu \mathrm{g}) / \mathrm{g}$ shows

where: $\mathrm{x}=$ is the concentration of carotenoids in the sample. And: volume of solution that gives the reading. To*: the extinction coefficient of $\beta$-carotene.

\subsection{Determination of total polyphenols}

Used $500 \mathrm{mg}$ of the sample a, b and c, is extracted with $40 \mathrm{~mL}$ of methanol/water (50:50 v/v) to $25{ }^{\circ} \mathrm{C}$ for 1 hour; saves the supernatant. The residual material is extracted with $40 \mathrm{~mL}$ of 
acetone/water $(70 / 30 \mathrm{v} / \mathrm{v})$ to $25^{\circ} \mathrm{C}$ for 1 hour; the supernatants are combined and concentrated in a rotary evaporator; the concentrate is dissolved in $10 \mathrm{~mL}$ of ethanol and the residue is dissolved in $10 \mathrm{~mL}$ of distilled water. Take $1 \mathrm{~mL}$ of the solution above both ethanolic aqueous solutions as and dilute to mark to $2.5 \mathrm{~mL}$ with $\mathrm{HCl}$ to $0.3 \%$. Take an aliquot of $50 \mu \mathrm{L}$ and adds in $1 \mathrm{~mL}$ of $\mathrm{Na}_{2} \mathrm{CO}_{3}$ to $2 \%$; added $50 \mu \mathrm{L}$ of Folin-Ciocalteau reagent diluted in water (1:1). After 30 minutes the absorbance is measured with the spectrophotometer at $750 \mathrm{~nm}$. The concentration of polyphenols is calculated using gallic acid as standard and the results are expressed as mg gallic acid per gram of fresh weight. (Mendez et al., 2013).

\section{RESULTS AND DISCUSSION}

\subsection{ABTS radical scavenging activity}

The antioxidant capacity of a food depends on the concentration and nature of the antioxidants present in these. The radical cation $\mathrm{ABTS}^{\circ+}$, it is widely used to measure the antioxidant capacity in fruits, as well as to measure phenolic compounds. The results obtained in this test are shown in table 1.

Table 1. Results of antioxidant activity of the radical cation ABTS

\begin{tabular}{cccc}
\hline Sample & $\begin{array}{c}\text { TEAC } \\
\text { \% reduction of } \\
\text { radical ABTS }\end{array}$ & 1 minute & 6 minute \\
\hline $\mathrm{a}$ & $69.21 \pm 0.92$ & $12.44 \pm 0.53$ & $13.87 \pm 0.87$ \\
$\mathrm{~b}$ & $36.60 \pm 2.11$ & $6.23 \pm 1.87$ & $5.62 \pm 1.98$ \\
$\mathrm{c}$ & $51.73 \pm 0.08$ & $7.98 \pm 0.33$ & $10.2 \pm 0.05$ \\
\hline
\end{tabular}

\footnotetext{
(a) fresh pipisco

(b) pipisco boiled

(c) preparation in sauce with pipisco

Data were expressed as the means \pm standard error of mean (SEM, $n=3)$

TEAC (antioxidant activity equivalent to Trolox)
}

Given the differences described in the times of measurement, you can compare the values of TEAC obtained in the different samples. In this study, we observed variations in the percentage of inhibition of the radical of a sample to another, showing that high temperatures affect the antioxidant capacity of a food. The results obtained in the sample $d$, were in a final concentration 
of $1000 \mathrm{mg} / \mathrm{L}$ using $990 \mu \mathrm{L}$ of ABTS with a absorbance of 0.700 to 0.702 more $10 \mu \mathrm{L}$ of the sample) (Table 2).

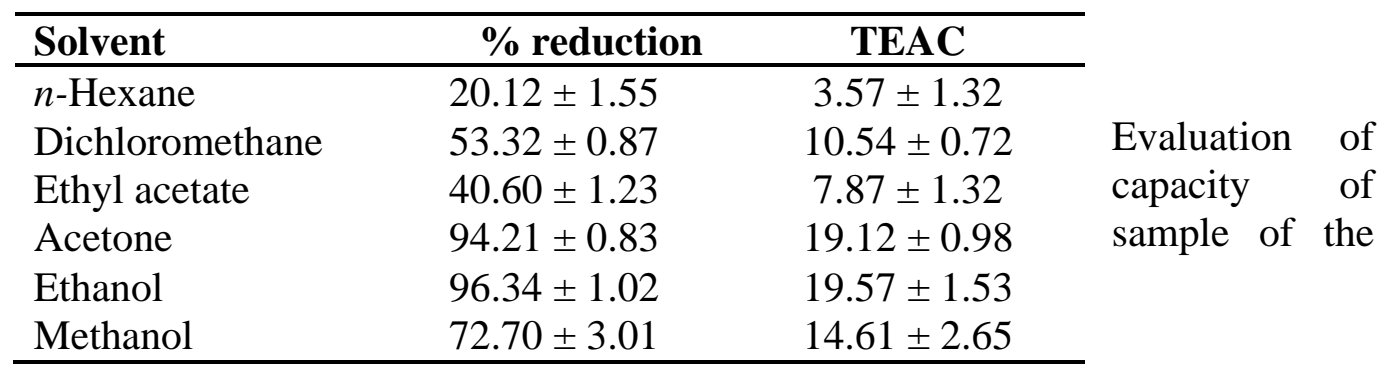

Data were expressed as the means \pm standard error of mean (SEM, $n=3$ )

TEAC (antioxidant activity equivalent to Trolox)

Pipisco extracts presented greater activity in acetone and ethanol solvent, the content metabolites

of high polarity can be responsible for example metabolites of type polyphenolics. The antioxidant activity in the radical reduction of ABTS is $20 \%$ lower that the tree tomato (Cyphomandra betacea) and $40 \%$ higher that the aguaymato (Physalis peruviana) both fruits of the same family, and, (Repo \& Encina, 2008). This test is specific to evaluate phenolic compounds as antioxidants. Nevertheless, developed other general tests as the defense evaluation the radical DPPH.

\subsection{Neutralization of free radicals by DPPH}

Assessed the antioxidant capacity contained extracts of pipisco to reduce the radical before mentioned, the percentage reduction was quantified by measuring the decrease in the absorbance at $517 \mathrm{~nm}$. The capacity of the radical reduction can be attributed to the donation of atoms of hydrogen. The results obtained in the samples a, b and c are represented in table 3 . 
Table 3. Reduction of radical DPPH.

\begin{tabular}{cc}
\hline Sample & $\begin{array}{c}\text { \% reduction of radical } \\
\text { DPPH }\end{array}$ \\
\hline $\mathrm{a}$ & $95.08 \% \pm 3.38$ \\
$\mathrm{~b}$ & $9.48 \% \pm 2.63$ \\
$\mathrm{c}$ & $78.53 \% \pm 0.58$ \\
\hline
\end{tabular}
(a) fresh pipisco
(b) pipisco boiled
(c) preparation in sauce with pipisco
Data were expressed as the means \pm standard error of mean (SEM, $n=3$ )

It is noteworthy that the sample a has an almost total inhibition of radical to the 30 minutes of reaction, similar to the one described in a study that evaluated by this method, the phenolic compounds in four different genotypes of "tomatillo" (Physalis ixocarpa), the results stand out in two of the samples approximate values to a $90 \%$ followed by a $55 \%$ and $28 \%$ of inhibition of the radical (González et al., 2010). In Figure 2 presents the results of the sample d. The extracts to 10 $\mathrm{mg} / \mathrm{L}$ of $n$-hexane and acetone were the most active in catch the radical $(3.43 \pm 1.22$ and $3.60 \pm$ $0.88)$ respectively while the least assets were extracts from dichloromethane and ethanol (1.76 \pm 1.83 and $2.06 \pm 1.05)$ the extracts which were well below the limits of detection were the ethyl acetate and methanol. 


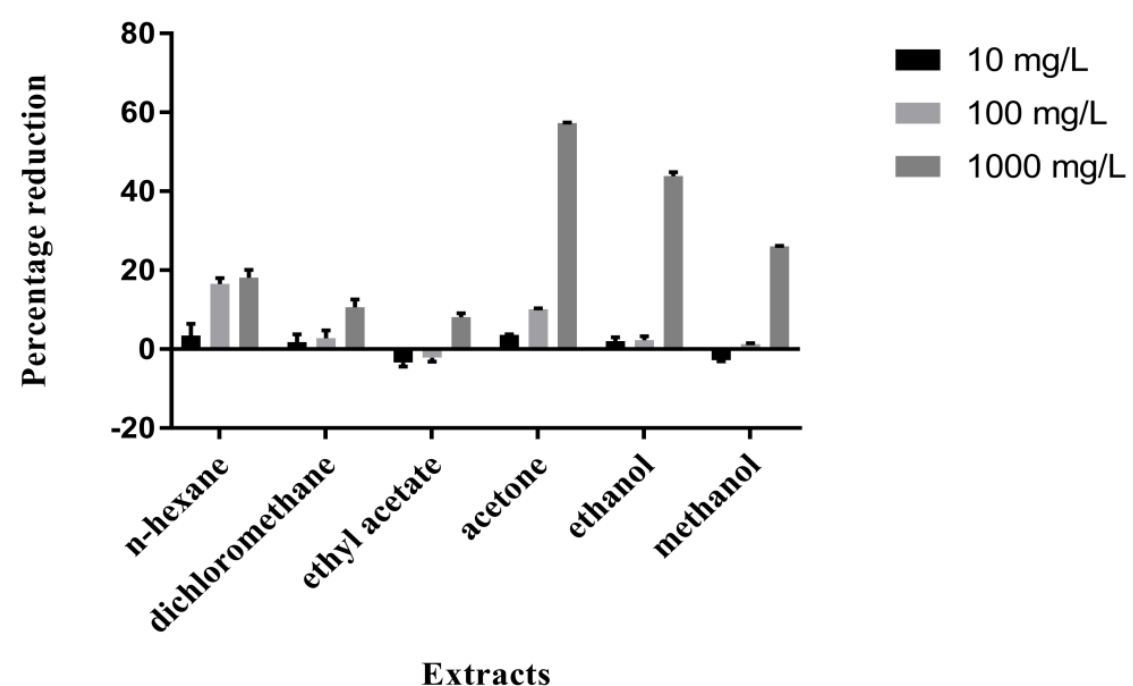

Figure 2. Percentage reduction of radical DPPH in extracts

We calculated the mean inhibitory concentration $\mathrm{IC}_{50}$ of the extracts of acetone and ethanol, obtaining 884.33 and $607.39 \mathrm{mg} / \mathrm{L}$ respectively.

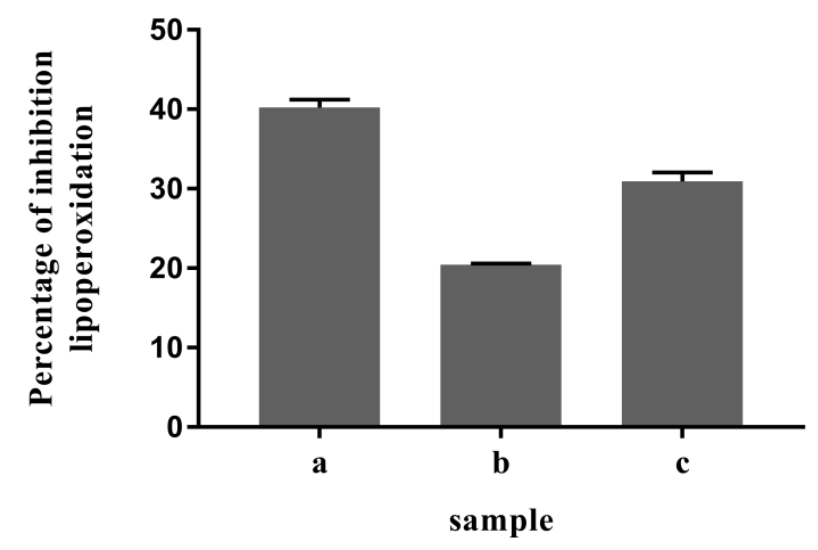

Figure 3. Percentage of inhibition of lipoperoxidation of radical TBARS
(a) fresh pipisco
(b) pipisco boiled
(c) preparation in sauce with pipisco
Data were expressed as the means \pm standard error of mean (SEM, $n=3$ )

The increased levels of lipoperoxidation have been correlated with cancer, atherosclerosis and the disease of Alzheimer and aging processes (Dorado et al., 2003). The MDA is one of the end products of lipid peroxidation of the cell membrane, (Pham et al., 2008) this reacts with the TBA to form a chromophore that was easily measured by spectrophotometry. The results of the inhibition of lipoperoxidation of samples a, b and $\mathrm{c}$ in the rat brain, are presented in Fig. 3. 
The polar extracts had a better result in the inhibition of the peroxidation of lipids, being the most active in this test, the acetone extract $(12.94 \pm 2.23)$ to $100 \mathrm{mg} / \mathrm{L}$ and the extract of ethanol $(2.51 \pm$ 1.43 ) to $10 \mathrm{mg} / \mathrm{L}$, as shown in figure 3 . In the same way is only calculated the $\mathrm{IC}_{50}$, the extracts more active, resulting in $548.80 \mathrm{mg} / \mathrm{L}$ for the acetone extract and $612.39 \mathrm{mg} / \mathrm{L}$ for the ethanol extract. The other extracts were not evaluated with regard to the calculation of the $\mathrm{IC}_{50}$ due to its poor performance as inhibitors of the antioxidant activity.

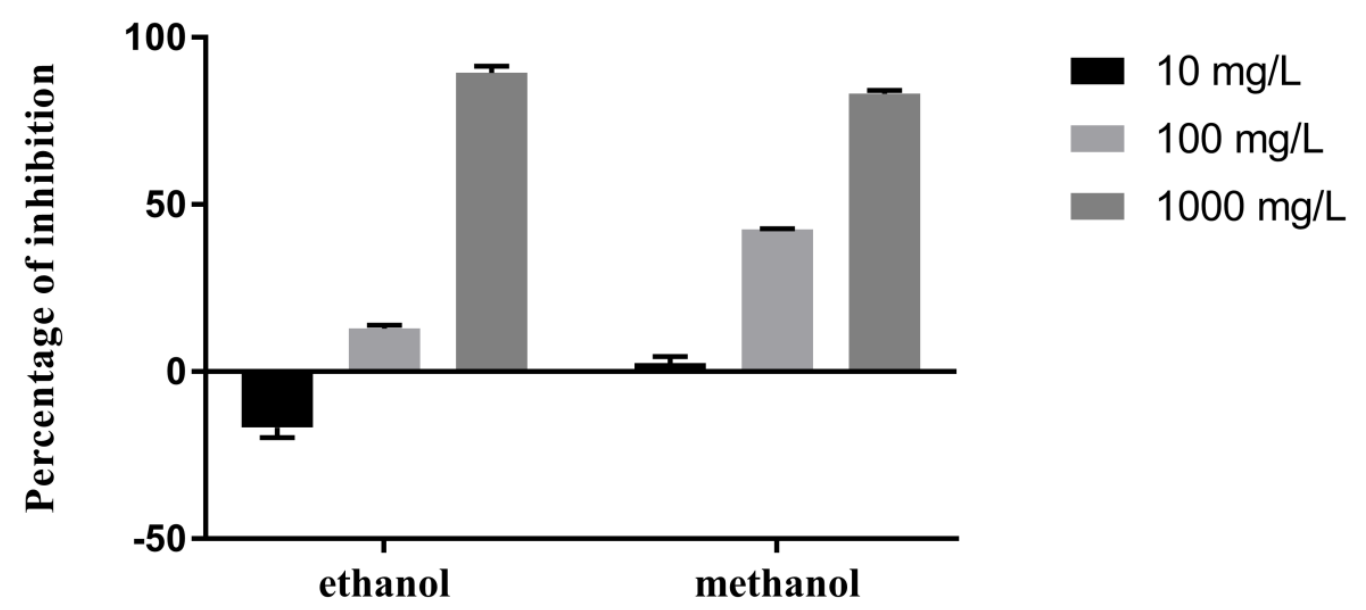

Extracts

Figure 4. Percentage of inhibition of lipoperoxidation in extracts

\subsection{Quantification of total carotenoids}

The antioxidant capacity is directly related with the pigment content of the fruit. In the tomato (Lycopersicon solanaceae), red color is attributed to the lycopene (Yaping et al., 2002; Zapata et al. 2007) identified the carotenoids present in the tomato, where the lycopene was the antioxidant with greater presence since it reported $18.93 \pm 9.68 \mu \mathrm{g} / \mathrm{g}$, and $0.44 \pm 0.25 \mu \mathrm{g} / \mathrm{g}$ of $\beta$-carotene. The results that were obtained in the test of total carotenes were $6.03 \pm 0.39,5.46 \pm 0.55$ and 6.68 $\pm 0.05 \mu \mathrm{g} / \mathrm{g}$ in samples $\mathrm{a}, \mathrm{b}$ and c respectively; compared with what is reported in the evaluation of $\beta$-carotene of two varieties of tomatillo, (Physalis philadelphic) and (Physalis ixocarpa) were high. The sample evaluated in this study were, in fresh $(0.21 \pm 0.03 \mu \mathrm{g} / \mathrm{mg}),(0.02 \pm 0.001 \mu \mathrm{g} / \mathrm{mg})$ and boiled $(0.21 \pm 0.01 \mu \mathrm{g} / \mathrm{mg}),(0.02 \pm 0.001 \mu \mathrm{g} / \mathrm{mg})$ (Elizalde \& Hernández, 2007).

The concentrations of the biological compounds change depending on the cooking process, demonstrating in this study the influence of temperature and the decrease of the biological activity 
of these compounds. This explains the decrease of total carotenes in the sample b. It was also noted during the conduct of the tests that the pipisco arrived to decrease or intensify their coloring, due to its content of anthocyanins, which are thermolabile and soluble in water, which causes them to be unstable (Garzón, 2008).

In this study, it was demonstrated that fresh pipisco, boiled and in sauce have a significant antioxidant capacity, that is the reason why is good choice of consumption. It was also observed an increase in the antioxidant activity in function of the incubation time to increase the antioxidant activity in neutralization tests of the DPPH, which can be regarded as a protective effect of prolonged antioxidants in against the danger of the material food oxidative. The sauce that was prepared with pipisco, is a sample of the combination of foods with high antioxidant capacity (onion and chili) although being subjected to high temperatures (roast) and mechanical processes (ground), there is no significant loss of antioxidants, so the pipisco can be a complement to some preparations as was done in ancient times.

\section{ACKNOWLEDGMENTS}

We thank Cesar Miguel López Méndez and Oscar Antonio Águilar Paredes for their technical contribution.

\section{CONFLICT OF INTEREST}

The authors have no conflict of interest to declare

\section{REFERENCE}

Benítez C. 2010. Sinopsis taxonómica del género Jaltomata (solanaceae) en Venezuela. Venezuela: Revista Facultad de Agronomía, Universidad Central de Venezuela. 36 (2): 72-80.

Candelas-Cadillo C., \& Alanís-Guzmán M. 2006. Cuantificación de licopeno y otros carotenoides en tomate y polvo de tomate. Revista Mexicana de Agronegocios. X(19)

Chuah M., Lee C., Yamaguchi T., Takamura H., Yin L., \& Matoba T. 2008. Effect of cooking on the antioxidant properties of coloured peppers. Food chemistry, 111(1), 20-28.

Davis T., \& Bye R A. 1982. Ethnobotany and progressive domestication of Jaltomata (solanaceae) in Mexico and Central America. Economic Botany 36(2): 225-241. 
Delgado-Olivares L., Betanzos-Cabrera G., \& Martínez-Sumaya M. 2010. Importancia de los antioxidantes dietarios en la disminución del estrés oxidativo: Investigación y Ciencia. 50: 11-13.

Dorado-Martínez C., Rugerio-Vargas C., \& Rivas-Arancibia S. 2003. Estrés oxidativo y neurodegeneración. Revista Facultad de Medicina UNAM. 46(6): 229-233

Elizalde-González M., \& Hernández-García S. 2007. Effect of cooking processes on the contents of two bioactive carotenoids in Solanum lycopersicum tomatoes and Physalis ixocarpa and Physalis philadelphica tomatillos: Molecules. 12(8): 1829-1835

Esterbauer H., \& Cheeseman K. 1990. Determination of aldehydic lipid peroxidation products: Malonaldehyde and 4-hydroxynonenal: Methods in enzymology. 186: 407-421.

Garzón G. 2008. Las antocianinas como colorantes naturales y compuestos bioactivos. revisión. Acta biologica Colombiana, 13(3): 27-36.

González-Mendoza D., Grimaldo-Juárez O., Soto-Ortiz R., Escoboza-Garcia F., \& Hernández J. 2010. Evaluation of total phenolics, anthocyanins and antioxidant capacity in purple tomatillo (Physalis ixocarpa) genotypes. African Journal of Biotechnology, 9(32), 5173-5176.

Halliwell, B. 2001. Role of free radicals in the neurodegenerative diseases. Drugs \& aging, 18(9): 685-716.

Hernández-Saavedra D., \& McCord J. 2007. Evolución y radicales libres. Importancia del estrés oxidativo en la patología humana. Revista Médica Instituto Mexicano del Seguro Social. 45 (5): 477-484.

Kibanova D., Nieto-Camacho A., \& Cervini-Silva J. 2009. Lipid peroxidation induced by expandable clay minerals: Environmental science and technology. 43(19): 7550-7555.

Krinsky N. 1989. Antioxidant functions of carotenoids. Free Radical Biology and Medicine. 7(6): 617-635.

Kuskoski M., Asuero A., Troncoso A., Mancini-Filho J., Fett R. 2005. Aplicación de diversos métodos químicos para determinar actividad antioxidante en pulpa de frutas: Food Science and Technology (Campinas). 25(4): 726-732.

Lowry O., Rosebrough N., Lewis-Farr A., Randall R. 1951. Protein measurement with the Folin phenol reagent: The Journal of biological Chemistry. 193(1): 265-275.

Luna-Guevara M., \& Delgado-Alvarado A. 2014. Importancia, contribución y estabilidad de antioxidantes en frutos y productos de tomate (Solanum lycopersicum L.). Avances en Investigación Agropecuaria. 18(1): 51-66

Magalhães L., Segundo M., Reis S., \& Lima J. 2008. Methodological aspects about in vitro evaluation of antioxidant properties. Analytica chimica acta, 613(1): 1-19. 
Martínez-Flores S., González-Gallego J., Culebras J., Tuñón M. 2002. Los flavonoides: propiedades y acciones antioxidantes: Nutrición Hospitalaria. XVII (6): 271-278

Mendez-Iturbide D., Banderas-Tarabay A., Nieto-Camacho A., Rojas-Chávez A., \& García-Mesa M. 2013. Antioxidant capacity of extracts from hawthorn (Crataegus mexicana) skin: African Journal of Food Science. 7(6): 150-158

Pham-Huy L., He H., \& Pham-Huy C. 2008. Free radicals, antioxidants in disease and health. International Journal of biomedical science. 4(2): 89-96.

Rainov G. 2000. A phase III clinical evaluation of herpes simplex virus type 1 thymidine kinase and ganciclovir gene therapy as an adjuvant to surgical resection and radiation in adults with previously untreated glioblastoma multiforme: Human gene therapy. 11(17): 2389-2401

Repo R., \& Encina-Zelada C. 2008. Determinación de la capacidad antioxidante y compuestos bioactivos de frutas nativas peruanas. Revista de la Sociedad Química del Perú: 74(2): 108-124.

Saldivar-Iglesias P., Laguna-Cerda A., Gutiérrez-Rodríguez F., \& Domínguez-Galindo M. 2010. Ácido giberélico en la germinación de semillas de Jaltomata procumbens (cav.) J. L. gentry. Agronomía mesoamericana 21(2): 327-331.

Sulbarán B., Sierra E., de Rodríguez G., Berradre M., Fernández V., \& Peña J. 2011. Evaluación de la actividad antioxidante del tomate crudo y procesado. Revista de la Facultad de Agronomía: 28(2).

Yaping, Z., Suping Q., Wenli, Y., Zheng X., Hong, S., Side Y., \& Dapu, W. 2002. Antioxidant activity of lycopene extracted from tomato paste towards trichloromethyl peroxyl radical $\mathrm{CCl}_{3} \mathrm{O}_{2}$. Food Chemistry, 77(2): 209-212.

Zapata L., Gerard L., Davies C., \& Schvab M. 2007. Estudio de los componentes antioxidantes y actividad antioxidante en tomates. Ciencia, docencia y tecnología, 35(18): 173-193 